\title{
Enkele opmerkinge oor die gewete
}

J A Heyns

ABSTRACT

Some remarks on conscience

The phenomenon of the human conscience has been not only the object of penetrating analysis through the centuries, but also a highly abused human faculty. The question can be asked: is conscience concerned only with man's relation to himself, or also with man's relation to God and to other men and even to institutions such as the state and the church? To certain people conscience pretends to be the voice of God within them and therefore the standard for the relation to other men. But in this case man himself became God.

Indeed conscience comes from a depth which lies beyond a man's own will and his own reason and it makes itself heard as the call to a normative unity with itself. From where does this call come and in what form does it present itself? An answer to this question would put conscience in the correct perspective.

Die aktualiteit vir besinning oor die gewete en met name oor gewetensvryheid, is onlangs weer beklemtoon toe, vir die eerste maal in die geskiedenis, 'n predikant van die Ned Geref Kerk geskors is omdat hy - in stryd met die besluit van die Sinode van daardie kerk - geweier het om vroue as ouderlinge te bevestig. Hiervoor het die predikant 'n beroep op sy gewete gedoen, gegrond op die feit dat die Skrif-volgens sy oordeel - dit nie toelaat nie.

Die meriete van die saak is hier hoegenaamd nie ter sprake nie, en daarna sal ook nie verder in die artikel verwys word nie. Maar wat hier wél aan die orde gestel gaan word is daardie boeiend interessante, hoogs persoonlike en uiters sensitiewe verskynsel in die menslike gees, naamlik sy gewete. Die vraag is hoe geldig is ' $n$ beroep op die gewete, met name as protes teenoor 'n objektiewe gesagsinstansie?

In die intra-individuele ek-ek-verhouding neem die gewete 'n uiters belangrike plek in en vervul 'n fundamentele funksie veral ten opsigte van die mens se handelinge en met name ten opsigte van die motivering daarvoor en die konkrete gestalte daarvan.

As hoogs persoonlike verskynsel is die mens nooit sonder sy gewete nie. Hy loop hom voortdurend teen sy gewete vas om steeds weer te ontdek dat dit sy gewete is, en niemand anders s'n nie. Nooit kan hy sy gewete ontvlug nie, want soos 'n skaduwee agtervolg sy gewete hom. As persoonsomvattende verskynsel, kan die gewete ook nie uitsluitlik tot die menslike wil, gevoel of tot die rede beperk word nie1. Die gewete het te doen met die totale menssyn én dus ook met die totale bewussynslewe waar dit gaan om onder andere die diepste gevoelens van vrees en angs, skaamte en vertwyfeling. As 'n eie-aan-die-gebroke eerlikheidsverskynsel sal die gewete, in die eintlike sin van die woord, moeilik vóór die sondeval in die persoon van die mens gevind kon word, soos wat die mens trouens ná die opstanding, in die toestand van volle verheerliking, ook nie meer 'n gewete sal hê nie. Die gewete het met die sonde in die wêreld gekom - aangesien dit vir die sonde bedoel is - en gaan ook weer met die sonde, die wêreld uit. As tipies-menslike verskynsel is dit duidelik 
dat die dier nie bedoel is om 'n gewete te hê nie. En terwyl God ook nie 'n gewete het nie - aangesien $\mathrm{Hy}$ b 6 die gewete staan - het die duiwel eweneens nie 'n gewete nie - omdat hy onder die gewete lewe. Maar wat is die gewete dan?

Wie 'n poging aanwend om na aanleiding van die literatuur, vas te stel presies wát onder die gewete verstaan word, beland spoedig in 'n labirintagtige verskeidenheid van opvattinge - 'n toedrag van sake wat juis die misteriekarakter van die gewete beklemtoon. Die gewete - so is al gesê - is die direkte neerslag van die openbaring van God in die mens, sodat die gewete met reg die stem van God genoem kan word. Maar die moderne mens, wat deur die proses van sekularisasie gevoer is na die outonomie van die gewete, het die stem van God, verander na: die stem van my beter-ek of die stem van die rede self. Dit is ook al verstaan as die stem van die gemeenskap, as die neerslag van die sedewet of as die oorblyfsel van die sedelike natuur in die mens - selfs as die bewussyn van ' $n$ inwendige geregshof, waar die gewete die rol van die regter of dié van die getuie speel. Nietemin, so word die gewete, en met name die gewete van die enkeling, 'n laaste beroep op en die hoogste en deurslaggewende gesag vir gesindheid, denke en handelinge. Maar het die gewete inderdaad so 'n onbetwisbare gesag in die lewe van die mens?

In 'n etimologiese analise van die gewete sou ons kon aantoon dat die woord ge-wete byvoorbeeld inherent 'n element van wete en met name 'n wete van 'n besondere aard insluit, en dat die Latynse woord vir gewete conscientia en die Grieks suneidesis is. Maar dit alles bring ons, ten opsigte van die bepaling van die wese en inhoud van die gewete nie veel verder nie'. Selfs al sou ons in 'n definisie of by wyse van 'n omskrywing sê dat die wesenlike van die gewete geleë is in die aanklaende en veroordelende funksie van die selfbewussyn, op grond van en opgeroep deur die openbaring van God, dan nog is daarmee nie al die nuanseringe in die werklikheid van die gewete, gedek nie. Geen wonder dan ook dat daar'n baie groot verskeidenheid van definisies vir of omskrywinge van die gewete aangetref word $n^{3}{ }^{3}$. Hoe hierdie beskouinge aangaande die gewete in die geskiedenis verander is en watter ontwikkeling daar ten opsigte van bepaalde insigte, waar te neem is - dit alles is vir ons doel hier nie nodig nie ${ }^{4}$. Behalwe dat ons kortliks tog by die opvatting van die skolastiek moet stilstaan, aangesien die onderskeidinge wat daar gemaak is, en die leer wat daarop gegrond is, groot invloed uitgeoefen het - selfs op latere, en ook nog op kontemporêre, reformatoriese denkers. 'n Basiese onderskeiding wat ten opsigte van die gewete gemaak is, en veral deur Thomas van Aquino, uitgewerk is, is dié tussen suntèrèsis en conscientia. Die suntèrèsis is die, in die mens aanwesige, stabiele vermoë waardeur hy in staat gestel word om die goeie te kies. Hierdeur word die, deur die sonde totale korrupsie van die mens, in 'n sekere sin gerelativeer, aangesien die suntèrèsis neerkom op 'n sondevrye, onfeilbare en onverwoesbare kern in die mens. Dit dui op 'n ingebore kennis van die sedewet wat 'n natuurlike wilsdrang by die mens tot die sedelik goeie opwek. Die conscientia is die eintlike gewete - ofskoon die suntèrèsis ook as deel van die gewete en met name as die oorsprong. agtergrond en die vir die sonde of dwaling ontoeganklike element van die gewete, beskou word. In die conscientia vind egter die beoordeling van die konkrete menslike handelinge volgens die maatstawwe van die suntèrèsis plaas. Die algemene kennis van laasgenoemde word langs die weg van redenasie, en met name die weg van die praktiese sillogisme, op die besondere handeling toegepas. Dat mens dus in die conscientia kan dwaal en foute maak, is vanselfsprekend. Maar daarin help die kerk dan ook. Hierdie gewetensleer het 'n 
groot invloed op die Rooms-Katolieke teologie gehad. Dit keer terug in die bewyse vir die bestaan van God, in die leer oor die sonde en die verlossing, en veral in die leer oor die goeie werke. Met die onderskeiding tussen suntèrèsis en conscientia, sowel as die funksie van die kerk in hierdie verband, het die Reformasie in beginsel gebreek. Veral is aangetoon dat hierdie sterk rasionalistiese gewetensleer, wat aanleiding gee tot 'n natuurlike teologie en 'n natuurlike sedeleer, basies niks anders is nie as die toepassing van die algemene Aristoteliese onderskeiding tussen moontlikheid en werklikheid. En met name is daarop gewys dat die suntèrèsisopvatting van die Middeleeue ongetwyfeld verwant is aan die Stoïsynse panteïstiese Godsbegrip en die daarop gegronde beskouing: om die natuur te volg, dit wil sê om gehoorsaam te wees aan jou eie binneste, is om God te volg.

Wend ons ons tot die Skrif is dit opmerklik dat die begrip gewete nie in die Ou Testament voorkom nie. Maar daarmee is nie gesê dat die Ou Testament nie die gewete ken nie, en nie belangrike gegewens bevat vir 'n beskouing oor die gewete nie. Die teologiese kategorieë waarin die oud-Israeliet dink is hoofsaaklik die verbond, die openbaring en die wet van God, terwyl die hiermee korrelerende antropologiese kategorieë dié is van gehoorsaamheid, geloof en vertroue (en natuurlik hulle teendeel) soos dit in die reaksies van die mens se hart, sy binneste, sy niere, ensovoorts geregistreer word ${ }^{5}$. Die ontwaking van die skaamtegevoel by Adam en Eva teen die agtergrond van die bewussyn dat die oorspronklike harmoniese bestaan met God, en met mekaar, skielik en wreed deur die sondeval versteur is, en die daarmee gepaardgaande verskeurdheid in hulle eie persoonlikhede, sal weliswaar nie as sodanig die gewete van Adam en Eva genoem kan word nie, maar sal tog beslis as die begin van die geskiedenis van die gewete, bestempel kan word. Hier gaan dit immers om die gewaarwording van Gods heilige teenwoordigheid aan Wie, ten opsigte van voltrokke handelinge, verantwoording verskuldig is, en aan Wie geen afdoende verantwoording gegee kán word nie (Gen 3:7 ev). Die verskynsel van selfbeskuldiging en selfaanklag en die daarmee dikwels gepaardgaande angs en skrik kom ook elders in die Ou Testament voor (vgl onder andere Gen 4:13; 26:10; 42:10; 50:15; Lev 26:36,40; Deut 28:65 ev; 1 Kon 2:44; Job 15:20 ev). Oral waar in die Psalms oor die bewussyn van skuld gepraat word, word implisiet ook oor die gewete gehandel (bv Pss 6, 32, 38, 42, 43, 51).

In die Nuwe Testament word suneidèsis gebruik en met gewete vertaal, ofskoon dit nie heeltemal is wat ons met gewete bedoel nie. Suneidèsis kan naamlik ook beteken: medewete, rekening hou met, bewus wees van, of gevoel vir. Dit kom voor onder andere in Romeine $2: 15 ; 1$ Korintiërs $4: 4$; Hebreërs $9: 14 ; 10: 22 ; 1$ Petrus $3: 21 ; 1$ Petrus $2: 19 ; 1$ Timotius $1: 5,19 ; 3: 9 ; 2$ Timotius $1: 3$; Hebreërs 9:9; 10:1. Hierdie en ook ander tekste gee enkele belangrike besonderhede aangaande die gewete. Die suneidèsis dui nie op 'n geheel ander funksie of 'n aparte orgaan as die hart waarmee die mens glo nie. Dit gaan nie om 'n oorblyfsel van natuurlike goedheid wat in die sogenaamde "gewetens-orgaan" gekonsentreer sou wees nie. Dit is eerder 'n bewus wees van en 'n wete van die geloof dat die lewe hom in gemeenskap met God, op die weg van heiliging bevind. In hierdie sin sou ons kon praat van 'n rein, en goeie gewete.

In Handelinge 23:1 ev sê Paulus dat, ten opsigte van alles uit sy lewe wat hom ten laste gelê kan word, sy gewete skoon is, en dus ten enemale swyg. Paulus wys hier dus op, wat ons sou kan noem 'n "goeie gewete" - 'n gewete wat gelyk is aan 'n swygende gewete, maar wat in feite dus geen gewete is nie! 'n Goeie gewete is 
immers, as negatiewe begrip, 'n negasie van die eintlike gewete. Maar daar is in die Nuwe Testament ook - en veral - sprake van die aanklaende en veroordelende gewete - 'n "slegte gewete" dus wat as positiewe begrip 'n bevestiging is van die eintlike gewete! So handel Paulus byvoorbeeld in Romeine 2:15 ev oor die gewete van die heidene wat hulle aankla oor hulle oortredinge. Hierdie aanklag spruit voort uit die feit dat die mens in sy gewete met die wet van God te doen het; in sy gewete dus deur die wet aangespreek word en daarom ook die stem van die wet moet beantwoord6. In 1 Korintiërs 8:7 ev handel Paulus weer oor die gewete van hulle wat nog swak in die geloof is. Wanneer hulle "offervleis" eet, eet hulle dit asof dit 'n afgodsoffer is, aangesien die oorgeblewe suggestie van afgode, nog in hulle denke 'n rol speel. Daarom moet diegene wat sterk is in die geloof 'n voorbeeld stel en nie "offervleis" eet nie. Hulle moet die gewete van ander ontsien - ook al is daar dwaling ten opsigte van objektiewe feitelikhede. Wanneer die geloofsband met Christus gevaar loop om verbreek te word in die lewe van hulle wat swak is in die geloof, moet hulle wat sterk is in die geloof, in vryheid van bepaalde regte afsien dit wil sê dit gaan hier om wat nie gedoen moet word nie, om nie 'n beskuldigende gewete te kry nie. Terwyl Paulus hier in 1 Korintiërs 8 die sterkes aanspreek ten opsigte van hulle gewetensverpligtinge teenoor die swakkes, spreek hy in 1 Korintiërs 10:25 ev weer die swakkes aan, en sê aan hulle: wees nie so bang om vleis te eet nie! Maak tog nie van alles 'n gewetenskwessie nie! - so kan alles in totale onsekerheid eindig. In beide gevalle is dit duidelik: die gewete vorm nie die laaste maatstaf van die mens se handelinge nie.

Die geheelboodskap van die Skrif is duidelik: die gewete is wel aanklaend besig (vgl Heid. Kat. S 23), maar staan in geen opsig bó die sondige verderf as orgaan waarop die mens hom vir sy relatiewe goedheid kan beroep nie. Die gewete kan dwaal en swak wees en kan, op grond van allerlei historiese veranderinge, fluktueer en vreemde stemme laat hoor. Die gewete $k a n$ ' $n$ aanduiding wees van disharmonie as gevolg van 'n eenheid van lewe wat verlore gegaan het en waarin die mens dit teen homself opgeneem het. Die gewete kan selfs ' $n$ nee voortbring en 'n protes laat hoor, maar 'n natuurlike lig wat tot ommekeer, tot boete en bevryding lei; wat 'n einde bring aan die korrupsie wat die mens van God vervreem - dit is die gewete beslis nie. Die gewete wys ons skuld voor God nie aan nie, al sê dit ook dat niemand volkome kan slaag in sy desperate vlug weg van die eise van die heilige en alomteenwoordige God nie. Nêrens word die eienskappe van onaantasbaarheid en heiligheid aan die gewete toegeken nie. Waar daar wel sprake is van 'n goeie (1 Tim 1:5,19), en skoon (Hebr 13:18; 2 Tim 1:3; Hand 3:1) gewete, is dit 'n aanduiding van die bewussyn van 'n lewe wat uit genade geregverdig is en in geloof op Gods weë wandel?. 'n Sistematiese verwerking van die Skrifgegewens oor die gewete sal uiteraard binne 'n teologies-antropologiese kader moet geskied. Hieroor hoef ons nie breedvoerig uit te brei nie. Ons wys slegs op die volgende: die mens, geskape deur Gods Woord, en vir Gods Woord, is bedoel om in Gods Woord te bestaan en te bly bestaan. Die menslike persoon is gevolglik nie 'n geslote, van God en medemens geïsoleerde, in homself rustende, outonome ek-wese nie. Hy is oop en reageer op bevele en opdragte van buite, en handel op motivering van binne. Die mens is dus as ' $n$ Woordbepaalde, vir die Woord vatbare en deur die Woord aanspreekbare wese, ook 'n tot ge-hoor-saamheid aan Gods Woord bestemde wese. Deur die Woord van openbaring hou God die mens in beweging en wel in die rigting van sy bestemmingsrealisering. 
As ons sê die mens is 'n Woordbepaalde wese - en hy is dit per definisie dan beteken dit twee dinge. Allereers: dat God die mens met sy'Voorsienigheidswoord ook direk ná die sondeval aangespreek het, en nog steeds bly aanspreek. En vervolgens: dat die mens, omdat hy ook ná die sondeval nog steeds beeld van God is, daarop reageer. In sy Woord tot ons, spreek God, die Heilige Gees, oor Homself, oor sy majesteit en heerlikheid, oor sy heiligheid en selfgenoegsaamheid. Hy spreek oor sy wil vir ons lewe, oor sy wet en sy gebod, én Hy spreek oor die mislukking van ons lewe gemeet aan die norm van sy wil vir ons. So dra die openbaringswoord aan die mens dus oor: 'n Godsbesef, 'n normbesef en 'n sondebesef. Deur hierdie Woord in die diepste kern van sy selfbewussyn onontwykbaar aangespreek, gaan die mens hierop antwoord. Maar sy antwoord kan die oorspronklike Woord - vanweë die ewidensie van sy inhoud - nooit tot volledige stilswye bring nie. Inteendeel. Sy antwoord word 'n weerklank van die Woord weliswaar, 'n deur die sondige menslike aandeel, verwronge en wanstaltige weerklank, maar nogtans 'n antwoord met 'n weerklank en 'n resonansie van die oorspronklike Woord. Dit wil sè, die mens se antwoord op die openbaring, dui op 'n sekere assimilasie of opname van die openbaringsinhoud in die menslike selfbewussyn - al mag dit nog so onvoldoende en verdraai daar uitsien. Omdat sy antwoord egter nie net 'n klank is van homself nie, maar iets van die weerklank van die Woord, word sy antwoord 'n oordeel - met ander woorde, hy oordeel homself! $\mathrm{Hy}$ word in sy selfbewussyn dus as't ware in twee "ekke" verskeur, terwyl die een "ek" die ander "ek" beskuldig en veroordeel. Hierdie "splitsing" in die mens, waardeur die een "ek" vreemd en aanvallend teenoor die ander "ek" te staan gekom het, het eers met die intrede van die sonde, in die mens ontstaan. Vóor die tyd het die mens in harmonie met homself gelewe, want hy het in die grootste harmonie en vrede met God gelewe. Tóe was hy immers nie deur só 'n Woord met só 'n inhoud aangespreek nie. In elk geval: hierdie, deur die openbaringswoord van God opgeroepte en deur die mens vergestalte selfaanklaende funksie van die selfbewyssyn, is die gewete.

In sy gewete weet die mens allereers dat hy "twee" is - "twee" wat vroeër wel, maar nou nie meer, in harmonie met mekaar lewe nie. Maar hy weet ook dat die "ander een" beter weet as "hierdic een": Die mens is dus in sy gewete 'n "beterweter". En waarom is hy 'n "beter-weter"? Nie omdat daar, diep in sy binneste, iets is wat die vernietigende werking van die sondeval, vrygespring het nie. Nee, op grond van Gods openbaringswoord aan hom, weet die mens met (van) God. Ons weet met Hom oor Hom en met Hom oor ons. Ons weet: God weet van ons, en ons weet wát God van ons weet ${ }^{8}$. Daarom is die mens in sy gewete 'n "beter-weter" omdat hy, en slegs in soverre as wat hy, 'n "mede-weter" met God is. In ons gewete weet ons baie meer oor ons, as wat ons uit onsself kan weet, maar ons weet oneindig minder oor ons, as wat God van ons weet. In die gewete ontmoet dus twee beweginge mekaar: ' $n$ appellerende beweging van bo na onder en 'n daarop reagerende beweging van onder na bo. So word die gewete 'n trefpunt van die goddelike Woord en die menslike antwoord. Maar tog nooit so dat die gewete die reine, ongerepte effek van die openbaringswoord is nie. Indien dit die geval was, dan moes die gewete tog altyd en oral, in dieselfde mens, en in alle mense, dieselfde inhoud hê. En op grond van ons ervaring weet ons dat dit nie die geval is nie. Die gewete is die deur die mens gevormde - en vanweë die werking van die sonde ook 
misvormde, effek van die openbaringswoord. Maar dan is dit tog 'n effek van die openbaringswoord.

Wanneer ons nou, in die lig van die voorafgaande, die gewete, in die intrasubjektiewe ek-ek verhouding, 'n dinamiese teo-antroposentriese gebeure noem, dan het ons daarmee verskillende belangrike aspekte van die gewete in die oog. Allereers die teosentriese fundering van die gewete. As dit nie die lewende God was - en is - wat met sy openbaringswoord die mens - ook ná die sondeval aangespreek het en nog steeds aanspreek nie, was daar van 'n gewete by die mens geen sprake nie. God se openbaring - met die spesifieke inhoud - is die transendente grond van die gewete - wat tegelykertyd ook verantwoordelik is vir die transendente inhoud van die gewete. Nie die gewete is voorwaarde vir die openbaring nie, maar omgekeerd: die openbaring is voorwaarde vir die gewete. Daarom is die gewete - vir sy ontstaan, voortbestaan én vryheid (waaraan ons later aandag gaan gee) van die openbaring, en die openbaring alleen, afhanklik. Met die teosentriese fundering van die gewete is alle vorme van evolusionistiese verklaringe vir die ontstaan en inhoud van die gewete, in beginsel dus verwerp. Hier is die gewete immers die blote neerslag van oorgeërfde sosiale en maatskaplike instinkte van die mens, gebaseer op die spanning tussen die egoïstiese neiginge in die mens en sy altruïstiese ideale. Die mens - so word geredeneer - moet hom in die harde bestaanstryd, self handhaaf, anders gaan hy onder. Daarom is die mens van nature egoïsties. Geleidelik ontdek die mens egter dat altruïstiese neiginge, nie alleen meer duursame vrugte oplewer nie, maar dat dit die gemeenskap ook beter dien. So begin dit dan ook vanself vir hom groter waarde kry. Maar wanneer daar nou 'n spanning tussen sy egoïstiese neiginge en altruïstiese ideale ontstaan, omdat die mens van nature teen laasgenoemde en vir eersgenoemde stry, ontwikkel hy 'n slegte gevoel, en só laat die gewete hom begin geld. Ten diepste is die gewete dus die reaksie van ons sosiale instinkte teenoor ons selfsugtige neiginge, en wat, uit die voorgeskiedenis van die menslike geslag, nog sterk in ons nawerk.

Vervolgens noem ons die antroposentriese substraat van die gewete. Die transendente inhoud van die gewete ontvang in en op grond van die werksaamheid van die menslike selfbewussyn, 'n immanente gestalte. Omdat die openbaring gerig is op en sy adres het in die diepste van die mens se bestaanskern, reageer die mens daarop as verantwoordelike wese teenoor sy Skepper en Wetgewer. Maar daarmee word die gewete dan ook 'n deur en deur menslike verskynsel, en 'n eksistensiële kategorie wat met die menssyn self gegee is. Van daar dan ook dat die gewete 'n uitgesproke individuele karakter dra. Die individualiteit van die gewete hang dan ook saam met, nee, beter gestel: vloei direk voort uit die individualiteit van die menslike persoon as beeld van God. Soos elke mens dus persoon is op 'n unieke, onvergelykbare wyse, so is ook sy gewete, uniek en onvergelykbaar syne en syne allecn. Maar die gewete is ook 'n deur en deur sondige verskynsel - eie aan my en my sonde alleen. Die gewete gaan nie uit bó, en staan nie los van, die sondige gebrokenheid van ons bestaan nie. Waar die tipiese van hierdie antroposentriese substraat van die gewete nie erken, of nie volledig erken word nie, daar word die gewete maklik oorskat. Eén van twee gebeur dan: of die gewete word beskou as direkte openbaring van God, sonder enige selfstandige tussenkoms van die mens, of die gewete word aanvaar as prestasie van die menslike gees alleen. In die eerste geval funksioneer die mens as blote reflektor wat die openbaring ontvang en onveranderd weerkaats, en in die tweede geval is die mens self die skepper van die 
gewete. Die merkwaardige is egter dat in beide gevalle die deur die sonde ongeskonde menslike natuur, die vóorveronderstelling uitmaak, met die gevolg dat die gewete in elk geval as 'n gesagvolle en betroubare bron beskou word wat in alle opsigte gehoorsaam behoort te word. Ten diepste het ons hier dus 'n humanistiese beskouing wat meen dat, indien nodig, die outonome gewete self innerlik tot berou en skuldbesef kan lei, en só die weg kan baan tot lewensvernuwing. Tot so 'n mate word die funksie van die gewete as sedelike selfbeoordeling soms oorspan, dat selfs die geloof daardeur bedreig word. Die "edele gewete" van die "verligte mens" word beledig deur die oproep om belydenis te doen van sonde en die leer van die versoening te aanvaar, waarin die blote gedagte van voldoening deur plaasvervanging, ' $n$ aanstoot is vir die sedelike besef van die mens'. Ook die Middeleeuse skolastieke opvatting van die suntèrèsis die sondevrye, onfeilbare kern in die mens, moet as humanisties van die hand gewys word. Nie in die mens nie, maar in die openbaringswoord van God, moet so 'n onfeilbare instansie gesoek word.

As derde belangrike aspek noem ons ten slotte die dinamiese karakier van die gewete. Die gewete is nie 'n statiese toestand waarin die bewussyn van die mens hom bevind nie. Die dinamiek van die gewete kan vanuit drie gesigspunte belig word. Allereers die permanente en voortgesette Openbaringswoord wat die Heilige Gces tot die mens rig. Hy het sy Woord nie net eenmaal gespreek en toe geswyg nie, maar spreek dit onophoudelik. Daarby moet ook nog genoem word die histories ontplooiende omvang en intensiteit van die sonde. As sonde die grond van die bestaan en die werksaamheid van die gewete is, dan is die moontlikheid van die gewete identies met die moontlikheid van die sonde. Ontwikkeling in laasgenoemde - waarop ook die Heilige Gees met sy Openbaringswoord reageer sal uiteraard ook die gewete nie onaangeroerd laat nie. En die derde rede vir die dinamiek van die gewete is in die menslike reaksie op die Openbaringswoord geleë. Die sensitiwiteit vir die werk van die Gees en die wyse van die menslike reaksie daarop, is afhanklik van die mens se gemeenskapslewe met God. Fluktuasies hierin - wat wissel tussen verinniging en vervlakking - sal eweneens die gewete beïnvloed. Juis hierdie dinamiek, wat deur verskillende faktore bepaal word, maak van die gewete ' $n$ kragtige faktor in of ' $n$ blote verskynsel op die randgebied van die innerlike lewe van die mens.

In die vasstelling van die betekenis van die gewete sal ons eers moet antwoord op die vraag of die gewete 'n spesifiek Christelike verskynsel is of nie. Indien net die gelowige 'n gewete sou hê, sou dit beteken dat nét die gelowige deur Gods Openbaringswoord aangespreek word, dat net hy sonde het, en dat net hy'n selfbewussyn het. Dat dit nie die geval is nie, is duidelik, sodat ons met sekerheid kan sê dat die gewete 'n tipies menslike en nie 'n eksklusief Christelike verskynsel is nie ${ }^{10}$. Maar daarmee is nie gesê dat daar nie verskille bestaan nie. Die gelowige, wat 'n nuwe skepsel is kragtens die wederbarende werking van die Heilige Gees, besit 'n wedergebore selfbewussyn, het deel aan die waarheid van Gods Verlossingswoord en ken die God wat hom aanspreek dus persoonlik. Daarby het hy reeds belydenis gedoen van sy sonde, berou daaroor getoon en is hy verseker dat hy van sy sonde verlos is - wat natuurlik nie beteken dat hy nie meer sondaar is, of nie meer sonde doen nie. Nietemin. Sy reaksie op die Openbaringswoord van die Heilige Gees, sy kennis van waarom dit gaan, sy insig in die wese van die sonde, sy begrip van en sensitiwiteit vir die betekenis van die gewete - dit alles lê tog op 'n totaal 
ander vlak as wat die geval is by die ongelowige. As die Christen dan 'n nuwe mens geword het, sal ons moet se dat sy gewete ook nuut geword het - al sou ons onmiddellik moet byvoeg dat ook sy gewete, soos sy ganse lewe, aan die proses van heiliging onderworpe is. Daarom sal die krag van die aanklaende gewete in direkte verband staan met die intimiteit van die gelowige se gemeenskap met God en sy Woord. Die paradoksale verskynsel doen hom in die lewe van die gelowige ten opsigte van sy gewete voor: waar versoening van sonde plaasvind, is die gewete vir die verloste mens in beginsel dus 'n verdwynende grootheid - en tog sál die gewete nie verdwyn nie, juis omdat ook die gelowige nog steeds sondaar is en sonde doen en die gewete die sonde moet aanwys. Daarom mág die gewete ook nie verdwyn nie - eties-goed handel die mens dan ook as hy sy gewete nie onderdruk nie, maar dit op alle moontlike maniere voed. Met name is die bewustelike normering van die gewete deur Gods Woord en veral die prediking van die wet, onontbeerlik om die gewete sensitief te maak vir die werklikheid van die sonde.

Die betekenis van die gewete is konkreet geleë in die feit dat dit 'n straf én genadegawe van God is. Dit is ' $n$ straf, want daardeur word die mens gemartel met pyn en wroeging by die besef van sy mislukking en sonde. Voor die majesteit en heiligheid van God kan hy nie bly staan nie, en onder sy toorn oor die sonde sal hy beswyk. Voor God en sy naaste staan hy skuldig en sy gewete herinner hom voortdurend aan die totale gebrokenheid van sy lewe. Daarom ervaar hy skaamte en eensaamheid, maar ook wanhoop en vertwyfeling. Maar naas die strafkarakter vertoon die gewete ook 'n genadekarakter. In sy openbaringswerksaamheid in die selfbewussyn van die mens, handhaaf die Gees die mens as 'n sedelike wese. Hy oorrompel die mens nie, en Hy skakel hom nie uit nie. Hy waarsku die mens en kla hom aan, en hierop kan die mens reageer. Die Gees laat die mens nie onaangeroerd in sy sonde bly lê nie, maar maak hom bewus van sy toestand. Aan die mens word gesê dat hy uit orde is, letterlik buite die orde wat God vir sy lewe daargestel het. Dit is tog genade as God in die gewete van die mens 'n soort grenswagter aanstel wat hom in die diepste diepte van sy bestaan bewus wil maak van sy oortredinge, en hom terugroep tot gemeenskap met God en sy naaste. Dáarom juis, is alle wanorde nie volledig chaos nie, en die wêreld nie volledig hel nie.

Laat ons dit duidelik stel: aan die verering van die gewete asof dit 'n direkte openbaring van God is wat bó alle wette verhewe is, en daarom onder alle omstandighede steeds gehoorsaam moet word, mag ons nie meedoen nie. Daarom sal ons dan ook met 'n beroep op die gewete, uiters versigtig moet wees ${ }^{11}$. Aan die ander kant sal 'n lewende omgang met Gods Woord die gewete voed en hom in sy funksie as aanklaer verskerp.

Aan die moeilike en ingewikkelde probleem van gewetensuryheid sal ons ten slotte ook nog aandag moet gee. Uitgaande van 'n bepaalde gewetens- én vryheidsopvatting word gewetensvryheid soms soos volg verklaar: allereers is dit die reg van ' $n$ mens om tot 'n eie vorming van gewetensoordele - soms ook net meningsvorming genoem - te geraak. Waar hierdie reg nie toegestaan word nie, of op enige wyse ook al ingeperk word, daar word gewetensvryheid bedreig of selfs as geheel en al vernictig. beskou. ' $n$ Tweede aspek van gewetensvryheid bestaan in die reg wat opgeëis word om die warheidsgehalte van die gewetensoordele sélf te beoordeel, en gevolglik te weier dat dit, met of sonder die tussenkoms of hulp van ander, aan enige objektiewe kriterium getoets sal word. Die derde aspek hestaan in 
die reg om in ooreenstemming met die gewetensoordeel te mag handel. Hoe moet ons hieroor oordeel?

In die lig van die begrip vryheid, en ons opvatting van die gewete waarby ons so pas stilgestaan het, behoort dit duidelik te wees dat ons hierdie beskouing oor gewetensvryheid nie kan onderskryf nie. Sonder om hierdie drie aspekte elkeen afsonderlik aan die orde te stel, gee ons kortliks bns mening oor hierdie beskouing. Natuurlik het elke persoon die reg - selfs die plig en die roeping - om in volle verantwoordelikheid sy eie gewetensoortuiging te vorm. Die reg mag niemand dan ook ontsê word nie - inteendeel, alles moet gedoen word om dit vir die ander moontlik te maak. Die reg op 'n eie gewetensoordeel en die plig om dié reg te eerbiedig, is 'n eties-goeie handeling. As die gewete iets uitdruk van wat die mens tot mens maak, en daarin sy sensitiwiteit ten opsigte van sy verantwoordelikheid tot openbaring kom, dan is almal - die medemens, die samclewing, die kerk en die staat - verplig om die persoon van die mens - ook in die aktiwiteit van sy gewetensvorming - met groot piëteit te bejeën. Wie dit nie doen nie, pleeg 'n onreg teenoor die mens. Gewetensvryheid is inderdaad een van die vrugte van die Christendom en 'n uiters belangrike geesteswaarde wat met krag verdedig moet word. In sy gewete staan die mens immers direk en onmiddellik voor God. Maar nou mag hierdie aspek van gewetensvryheid nie in individualistiese en subjektivistiese sin misverstaan word nie. Dit gebeur wanneer gewetensvryheid uitsluitlik gesien word as ' $n$ intiem persoonlike aangeleentheid wat of in die intra-individuele selfbewuste ek-ek-verhouding, of in die interpersoonlike ek-God-verhouding gesetel is. In beide gevalle word die ander - die naaste, die samelewing, die kerk en die staat - in tipiese liberalistiese sin, volledig uitgesluit. Natuurlik is die gewete 'n persoonlike aangeleentheid - dit het ons vroeër tog duidelik beklemtoon - maar dit sluit die inbreng van die ander, en die rekening hou met die ander, nooit uit nie. Waar dit wel gebeur, het ons met ' $n$ grenslose subjektivistiese individualisme te doen. En dit bring ons meteens ook by 'n volgende gedagte. Die gewete, het ons gesien, is nie onfeilbaar nie, en nie die einde van alle teenspraak nie. Geen mens het die reg om sy eie subjektiewe gewetensuitspraak as die hoogste en beslissende norm - vir homself of vir ander - te proklameer nie. Hy kan tog in sy gewete dwaal! En daarom sal hy ook gewillig moet wees om sy gewetensuitspraak aan 'n objektiewe norm te toets, of deur ander te laat toets. Trouens, die bereidheid tot objektiewe toetsing behoort juis tot die diepste en edelste eienskappe van 'n egte en legitieme gewetensoordeel. Waar die bereidheid ontbreek, het ons met 'n pseudo-gewetensoordeel te doen. Die beskouing dat die gewete as die hoogste norm aanvaar moet word, vloei voort uit, en word gerugsteun deur'n siening dat die gewete outonoom is, en gevolglik in volledige soewereiniteit sy uitsprake kan maak en sy eise kan stel. Hierdie outonomie van die gewete impliseer dat die gewete in beginsel los is - en steeds in praktyk dus bevry moet word - van elke vorm van heteronomie, dit wil sê van alle norme wat van buite die persoon afkomstig is. Maar dan het ons ook nie meer met gewetensvryheid nie, dog met reine vrydenkery te doen.

Die vorming van 'n eie gewetensoordeel, is 'n beginsel wat erken en eerbiedig moet word. Hieraan moet steeds en onder alle omstandighede vasgehou word. By die enkele kwalifikasies wat ons egter reeds, ten opsigte van die vorming van 'n gewetensoordeel gevoeg het, wil ons nou nog 'n laaste, maar uiters belangrike opmerking maak en wel ten opsigte van die hantering of implementering van so 'n gewetensoordeel. Eties is ook dit immers nie 'n onverskillige saak nie. Wanneer so 
'n outonome, subjektivisties-individualistiese gewetensoordeel nou ook na buite propagerend gestel word, en in geskrewe of gesproke woord en daad begin vorm aanneem, dit wil sê werfkrag begin verkry en ondermynende resultate oplewer, begin uiteraard 'n ernstige konflik tussen enkeling en samelewing. Elke samelewing veronderstel per definisie orde en reëls, en juis dit impliseer 'n baie hoë mate van uniforme en gelykvormige optrede. Indien elkeen dus die reg sou hê en inderdaad toegelaat sou word om volgens sy eie "gewetensoortuiging" te handel, byvoorbeeld dat vrye huwelike in orde sou wees, dat militêre diens geweier kan word, dat arm mense van ryk mense mag steel, dat elke verontregting deur die verontregte self gewreek moet word, dat sinodale besluite sonder meer verwerp mag word, indien dit alles deur elkeen na willekeur gedoen kan word, sal dit nie anders kan nie, as dat die samelewing in volledige chaos en wanorde eindig. Hoe belangrik gewetensvryheid dus ook al mag wees, 'n onbegrensde uitlewing van 'n bepaalde gewetensoortuiging kan in geen menslike samelewing toegelaat word nie. Wie dus sulke antisosiale en anargistiese gewetensoortuiginge daarop nahou, sal verlief moet neem as daar deur instansies wat met die handhawing van orde in die samelewing belas is, soos byvoorbeeld die staat, teen hom opgetree word - ten minste, wat die uitlewing daarvan betref; die vorming daarvan en die geloof daarin, bly natuurlik sy eie persoonlike verantwoordelikheid.

Maar as gewetensvryheid nie in subjektivistiese willekeur of in individualistiese selfbeskikking bestaan nie, waarin bestaan dit positief dan wel? In die algemeen wil ons sê is gewetensvryheid die gebondenheid aan sowel die wetmatigheid wat geld vir die vormingsproses van gewetensoordele as die gebondenheid aan die eise wat deur die gewetensoordele self aan die mens gestel word. Meer in besonder kan ons sê is gewetensvryheid die deur die openbaring van God genormeerde selfontplooiing soos dit binne die kader van die intra-individuele ek. $e k$-verhouding afspeel. In hierdie omskrywinge is daar enkele sake waaraan ons kortliks aandag moet gee.

Die mens wat hom in sy gewete gebonde ag aan die Openbaringswoord wat hom aanspreek, is vry. Die gewete vind sy inhoud, het ons vroeër gesien, nie in homself nie, maar buite homself, en daarom sal die immanent geformuleerde gestalte steeds aan die objektiewe kriterium getoets moet word ${ }^{12}$. Daarom is gewetensvryheid nie net die feitelike ooreenstemming tussen die immanent geformuleerde gestalte van die gewete met sy transendentbepaalde inhoud nie, maar ook die daadwerklike gebondenheid daaraan. Hierdie hoër instansie of objektiewe kriterium waaraan die gewete onvoorwaardelik gebonde is, is uiteraard nie net Gods Voorsienigheidswoord nie, maar ook sy Skrifgeworde Woord - anders gesê: is nie net die algemene openbaring nie, maar ook die besondere openbaring. Trouens, die boodskap en inhoud van die Voorsienigheidswoord moet steeds in die lig van die Skrifgeworde Woord verstaan en geïnterpreteer word. Alleen wanneer, en alleen insoverre die gewetensoordele gegrond is in, en ooreenstem met, of op sy minste, nie beteken 'n verwerping van die eise van Gods Woord nie, is daar van gewetensvryheid sprake. Daarmee is in beginsel gegee sowel die wesenlike eenheid van die gewetensvryheid van alle mense, as die onderlinge differensiasie tussen die gewetensvryheid van verskillende mense. Ook die gewetensvryheid ken immers die beginsel van harmoniese differensiasie. Die gewetensvryheid van die een kán dus nie - in beginsel altans - in botsing wees met dié van 'n ander nie - of die ander nou ook al individueel of kollektief verstaan word. 
In feite vind botsings natuurlik wél plaas. Om dit konkreet te illustreer. Die spanning tussen owerheid en enkeling spreek duidelik wanneer laasgenoemde verklaar: "uit die krag van my diepste oortuiging moet ek verklaar dat ek in beginsel teen die doen van militêre diens is en vra daarom om ontheffing daarvan". 'n Etiese beoordeling van hierdie dilemma sal moet begin by die vraag of ons hier werklik met 'n gewetensbeswaar te doen het, waarby gewetensvryheid op die spel is? Kan die beswaarde hom op 'n opdrag van God beroep waarin eksplisiet gesê word dat niemand ooit gedood mag word nie? Selfs die sesde gebod kan nie hiervoor aangehaal word nie. Wat hier verbied word is nie alle doding sonder meer nie, maar slegs die wederregtelike en dus onbevoegde doodmaak van 'n mens - die doodmaak sonder opdrag. Dit gaan hier dus om dood as moord en nie om dood as straf nie. Die konflik is duidelik: enersyds die vermeende gewetensoordeel van die enkeling, en andersyds die plig van die owerheid, van Godsweë, om die land te verdedig, en gevolglik die reg om die swaard te hanteer en mense - nie te moor nie - maar in opdrag dood te maak. Dit is duidelik: die owerheid kan homself nie van sy verantwoordelikheid onthef nie, aangesien hy dit nie self aan hom opgedra het nie. Die owerheid sal hom moet hou aan die eise van Gods besondere openbaring in die Skrif, en sy optrede in hierdie wêreld daardeur en daardeur alleen laat normeer. Terselfdertyd moet die gewete, as vrug van die algemene openbaring wel in aanmerking geneem word - aangesien dit in diens van die moraliteit kan wees maar eerbiedig kan dit eers, wanneer dit inhoudelik nie in stryd is met die besondere openbaring nie. Hier word die inhoud van die gewetensoordeel - deur die owerheid - dus getoets aan die inhoud van die besondere openbaring. En wanneer dit die toets van hierdie objektiewe kriterium nie slaag nie, moet die vraag gevra word: het ons hier wel met gewetensbesware te maak, of bloot met gemoedsbesware, politieke besware of met filantropiese besware? Eweneens moet die vraag gevra word of die besware op grond waarvan die soldaat byvoorbeeld weier om ' $n$ verpligte godsdiensparade in sy basis of in die veld by te woon, as gewetensbesware beskou moet word. Afgesien daarvan dat die dienspligtige, reeds by sy indienstreding, presies weet watter vorme van "diens" - dus ook "godsdiens" vir hom wag, kan tog nie aanvaar word dat die Openbaringswoord wat hom in sy gewete aanspreek, hom teen godsdiens sal waarsku nie. Ook hier het ons nie met gewetensbesware te maak nie, maar hoogstens met godsdiensbesware. 'n Staat wat hom in sy grondwet verbind het om die lewende God in al sy handelinge te ken en te gehoorsaam, sal hierdie soort "gewetensvryheid" dan ook nie kan eerbiedig nie deur dit egter wel te doen gee hy toe aan en werk hy mee aan 'n onverskilligheid teenoor en ' $n$ afkeer aan die heilige God ${ }^{13}$. Net so min as wat die staat kan toelaat dat iemand deur woord, geskrif of voorbeeld, onsedelikheid propageer en so die etiese grondslae van die samelewing ondermyn, of die veiligheid van die staat en daardeur die voortbestaan van die staat self, in gevaar stel, net so min mag die staat godslastering toelaat - want daardeur word sy eie Opdraggewer beledig. Gewetensvryheid sal dan alleen eerbiedig mag word wanneer die gewete self aan bepaalde algemene norme gebonde is en juis dárdeur agting by die staat afdwing. Wie hierdie agbaarheid van die gewete egter deur illegitieme oordele en eise verbeur, het geen regsgronde om eerbied vir sy gewetensoortuiging te verwag, of ruimte vir sy gewetensvryheid te eis nie.

Wanneer eenmaal vasgestel is - deur eie toetsing en/of met behulp van ander - dat die grootste moontlike kongruensie tussen die Openbaringswoord en die 
menslike antwoord daarop bereik is, dit wil sê dat die gewete in volledige oore enstemming is met die wil van God, - wanneer dit vasstaan, sê ons, is gewetensvryheid om daaraan vas te hou, teen die oordeel (en die optrede) van almal in - selfs teen staat en kerk in. Klassieke voorbeeld hiervan is natuurlik Martin Luther se optrede by die Ryksdag van Worms. Aan die einde van sy verdediging het hy afgesluit met die later bekende en ook beroemd geworde woorde: "Hier staan ek, ek kan nie anders nie". Dit het hier nie gegaan om 'n feitlike onmoontlikheid nie. Dit was vir hom nie onmoontlik om sy geskrifte te loën en sy standpunt terug te trek nie. Hy was immers nie soos 'n persoon wat deur verdowingsmiddels verlam was en dus nie fisies kon beweeg nie. Dit het ook nie gegaan om 'n normatiewe onmoontlikheid nie. Dit was nie 'n kwessie dat hy eintlik graag sou wou doen wat hom gevra is nie, maar dat dit vir hom helaas verbode was, en dat hy dit dáárom nie kon doen nie. Ewe min was dit 'n psigiese onmoontlikheid. Iets in die sin van: "ek sou dit in die lig van die oorweldigende aandrang kon en selfs wou oorweeg, maar ek is bevrees dat alles nou te ver gegaan het en kan ek dit, vanweë die moontlike nadelige gevolge daarvan, nie meer terugtrek nie". Nee, met daardie woorde het hy gesê dat dit vir hom om 'n gewetensonmoontlikheid gegaan het. Hy kon nie anders nie, en hy wou ook nie anders, want hy was in sy gewete aan God, en aan Hom alleen, gebind. Dit was ten diepste God wat hom gebied het om só te handel, en hom verbied het om anders te handel. Dit is gewetensvryheid! Om ' $n$ verheerliking van die gewete as sodanig. om die majesteit van die persoonlikheid of die onfeilbaarheid van die eie mening te proklameer - dároor gaan dit nie, maar wél om die gebondenheid van die gewete aan die openbaring van God. Los van alle menslike gesag en bindinge - maar by geleentheid ook met behulp daarvan - is gewetensvryheid alleen diens aan God.

\section{NOTAS:}

1 Vergelyk Th Haitjema, Dogmatiek als apologie, Haarlem 1948, 124.

2 G Kittel, Theolische Wörterbuch Bd VIl, S.V. Sunoida 879 ev; W J Alders, Handoek der ethiek, Amsterdam 87 ev.

3 Dit spreek vanself dat ' $n$ enorme groot aantal wyduiteenlopende definisies in die literatuur aangetref word. Sien onder andere G Heymans, Einführung in die Ethik, Leipzig 1914, 290; W J Aalders, a w, 37; A Kuyper, De gemene gratie, deel 1, Kampen 1932, 161; vergelyk sy E Voto Dordraceno, deel III, Amsterdam 1905, 501-502; H Bavinck, Gereformeerde Dogmatiek III, Kampen 1929, 177; Ernst Wolf, Sozialethik. Theolische Grundfragen, Göttingen 1975, 59; R Schipper, in: Christelijke Encyclopedie, Bd 3, S.V. geweten, Kampen 1958, 217; K Barth, Kirchliche Dogmatik 2/1 ZollikonZürich 1946, 614-615, vergelyk ook 636; Kirchliche Dogmatik IV/2, 350; vergelyk Kinchliche Dogmatik IV/4, 124.

$4 \quad V i r$ 'n oorsig oor die historiese ontwikkeling van die gewete-begrip sien onder andere P Prins, Het geweten, Delft 1937, 196, en E Wolf, a w, 59 ev.

5 Vergelyk 1 Samuel 24:6 en 2 Samuel 24:10 in verskillende vertalinge. 
6 Kyk onder andere H Ridderbos, Aan de Romeinen, Kampen 1959, 61 en A F N Lekkerkerker, De Brief van Paulus aan de Romeinen 1, Nijkerk 1971, 100 ev se eksegese van dié teks.

7 Calvyn sê 'n goeie gewete is niks anders nie as 'n inwendige suiwerheid van hart (Inst. IV/10/4).

8 Vergelyk Karl Barth, Kirchliche Dogmatik 11/1, 614, 615.

9 C Bezemer, (Het Christelijk geweten bij A Vinet, Kampen 1966) gee aandag aan beskouinge oor die gewete in die kring van die etiese teologie.

10 Vergelyk Calvyn, Institusie 1/111/2, 1/VII/4, 1/VII/1, iii/xix/15. Sien ook H Thielicke, Theologische Ethik 1, Tübingen 1965, 501.

11 P Prins, $a w$, 54a merk selfs op: "Daarom moet onder Christene het beroep op het geweten nog veel meer nagelaten word dan ergens elders".

12 Bezemer, $a w, 107$, onderskei - myns insiens ten onregte - tussen vryheid van die gewete en gewetensvryheid. K Barth sê gewetensvryheid is nie om aan iemand toe te staan om te dink wat hy "fyn" vind nie, " sondern die von Gott in seiner Offenbarung denen, die sie annehmen, mitgeteilte Möglichkeit, das zu denken, was in seinem Gericht das Rechte und also wahr und weise ist" (K.D. 1/2, p 780).

13 Vergelyk Nederlandse Geloofsbelydenis artikel 7 en 32, en Calvyn Institusie IV/10,7,8, Bavinck, a w, $392 \mathrm{ev}$. 